\title{
Debris Flow from 2012 Failure of Moraine-Dammed Lake, Three Fingered Jack Volcano, Mount Jefferson Wilderness, Oregon
}

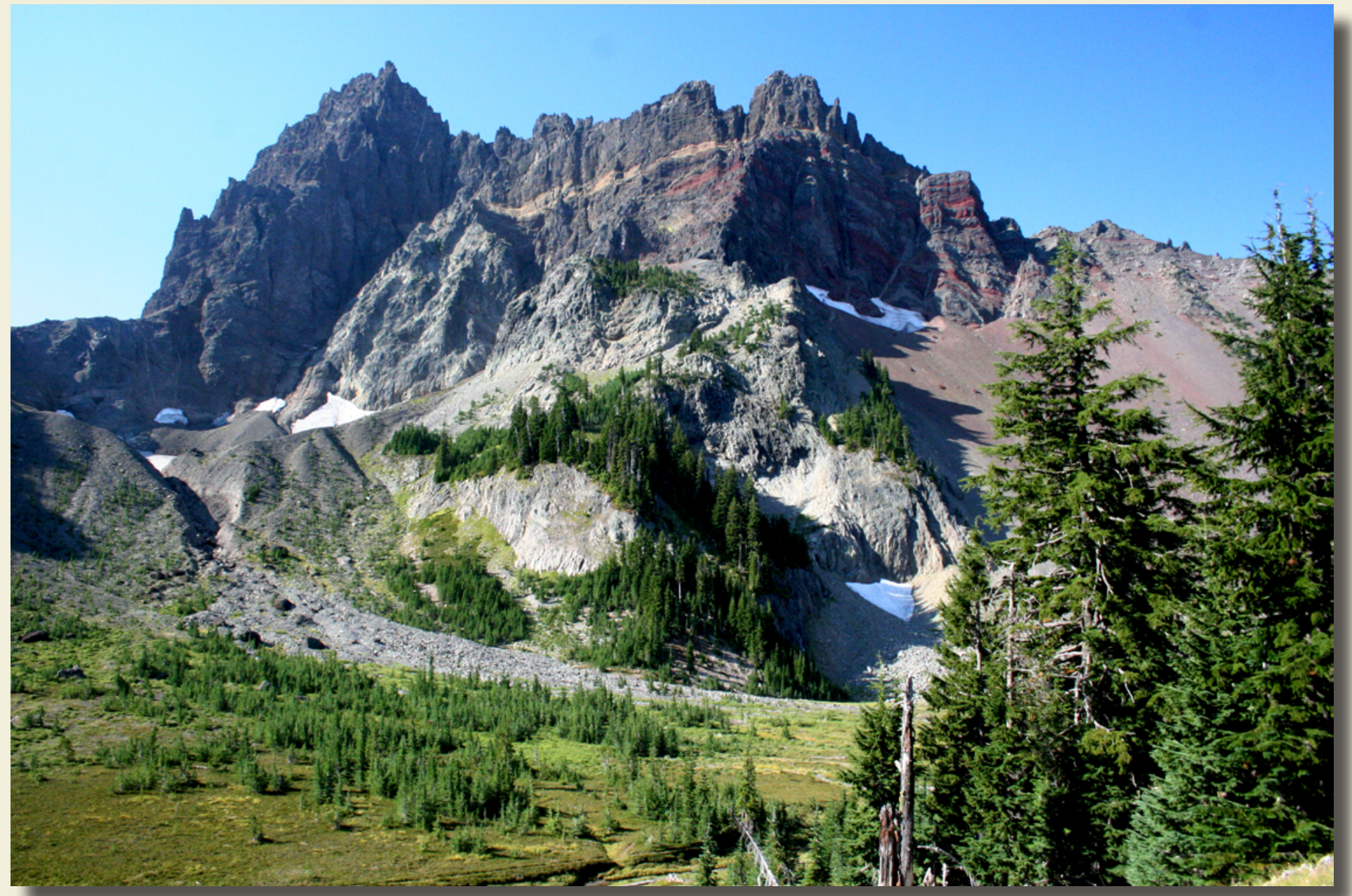

Scientific Investigations Report 2014-5208 
Cover photograph:

View southwest across head of Canyon Creek drainage on September 15, 2013. Neoglacial moraine lies left of center, notched by the narrow canyon that drains cirque lake. Debris flow of 2012 shed its bouldery deposits downslope from the mouth of the canyon. Highest point on skyline is summit of Three Fingered Jack. 


\section{Debris Flow from 2012 Failure of Moraine- Dammed Lake, Three Fingered Jack Volcano, Mount Jefferson Wilderness, Oregon}

By David R. Sherrod and Barton B. Wills

Scientific Investigations Report 2014-5208 


\section{U.S. Department of the Interior SALLY JEWELL, Secretary}

\section{U.S. Geological Survey \\ Suzette M. Kimball, Acting Director}

\section{U.S. Geological Survey, Reston, Virginia: 2014}

For more information on the USGS - the Federal source for science about the Earth, its natural and living resources, natural hazards, and the environment—visit http://www.usgs.gov or call 1-888-ASK-USGS

For an overview of USGS information products, including maps, imagery, and publications, visit http://www.usgs.gov/pubprod

To order this and other USGS information products, visit http://store.usgs.gov

Any use of trade, firm, or product names is for descriptive purposes only and does not imply endorsement by the U.S. Government.

Although this information product, for the most part, is in the public domain, it also may contain copyrighted materials as noted in the text. Permission to reproduce copyrighted items must be secured from the copyright owner.

Suggested citation:

Sherrod, D.R., and Wills, B.B., 2014, Debris flow from 2012 failure of moraine-dammed lake, Three Fingered Jack volcano, Mount Jefferson Wilderness, Oregon: U.S. Geological Survey Scientific Investigations Report 2014-5208, 13 p. http://dx.doi.org/10.3133/sir20145208.

ISSN 2328-0328 (online) 


\section{Contents}

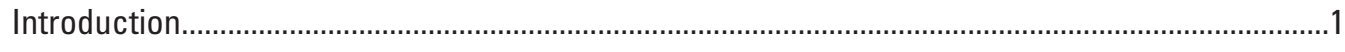

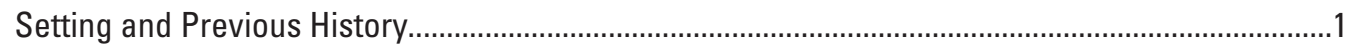

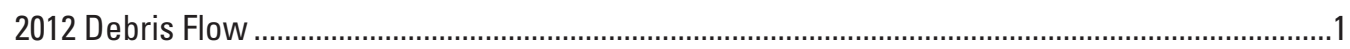

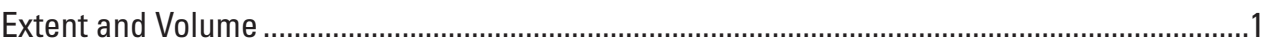

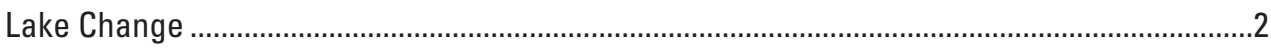

Cause and Timing of the Moraine-Dam Failure …….................................................................

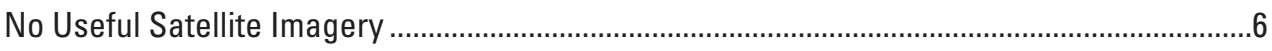

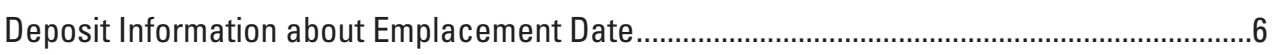

Inferred Snow Conditions ...................................................................................................

Anecdotal Information about Emplacement Date ..................................................................

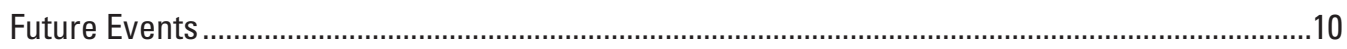

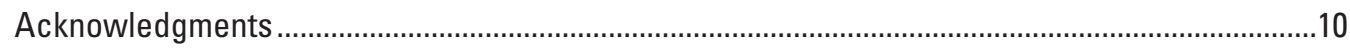

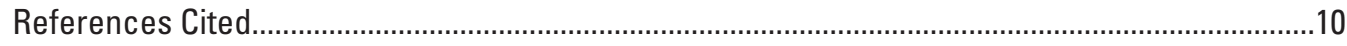

Appendix A. Unrelated, Subsequent Snow Avalanche Dumped Trees onto the Snout of the

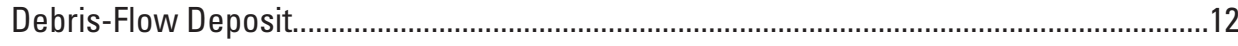



\section{Figures}

1. View south-southeast across debris-flow deposits to neoglacial moraine, $500 \mathrm{~m}$ distant ....2

2. Map showing distribution of 2012 debris-flow deposit from moraine-dammed lake failure on northeast flank of Three Fingered Jack, Cascade Range, central Oregon ...................3

3. Cirque lake and lateral and terminal moraines on northeast flank of Three Fingered Jack...4

4. View south-southeast into canyon that heads at moraine-dammed lake ...............................

5. Bouldery debris-flow deposit atop $1.5 \mathrm{~m}$ of snow, winter 2011-12 snowpack .......................5

6. Time-volume graph for moraine-dammed lake on northeast flank of Three Fingered Jack ..5

7. View north along west side of lake ..............................................................................

8. Highest(?) shoreline on west side of lake, $6 \mathrm{~m}$ above 1993 shoreline and $8.8 \mathrm{~m}$ above



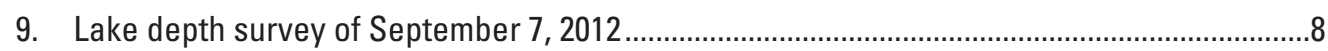

10. Snow thickness plot. Mount Hood data are from SNOTEL Site 651 for May, June, and July

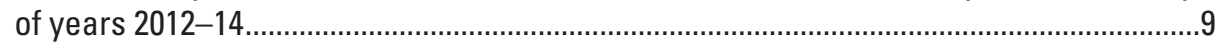

A1. Graph showing Timberline (Mount Hood) precipitation and temperature data.....................12 


\section{Tables}

1. Geometric parameters for lake in northeast cirque of Three Fingered Jack .........................6

B1. Index to key features of the lake and debris fan as discussed in O'Connor and others (2001). 


\section{Conversion Factors}

Inch/Pound to SI

\begin{tabular}{lcl}
\hline & Multiply & \multicolumn{1}{c}{ By obtain } \\
\hline inch (in.) & Length & \\
inch (in.) & 2.54 & centimeter (cm) \\
foot (ft) & 25.4 & millimeter (mm) \\
mile (mi) & 0.3048 & meter (m) \\
yard (yd) & 1.609 & kilometer (km) \\
\hline & 0.9144 & meter (m) \\
\hline acre & Area & \\
square mile $\left(\mathrm{mi}^{2}\right)$ & 0.4047 & hectare (ha) \\
\hline & 259.0 & hectare (ha) \\
\hline cubic foot $\left(\mathrm{ft}^{3}\right)$ & Volume & \\
\hline
\end{tabular}

Temperature in degrees Celsius $\left({ }^{\circ} \mathrm{C}\right)$ may be converted to degrees Fahrenheit $\left({ }^{\circ} \mathrm{F}\right)$ as follows: ${ }^{\circ} \mathrm{F}=\left(1.8 \times{ }^{\circ} \mathrm{C}\right)+32$

Temperature in degrees Fahrenheit $\left({ }^{\circ} \mathrm{F}\right)$ may be converted to degrees Celsius $\left({ }^{\circ} \mathrm{C}\right)$ as follows: ${ }^{\circ} \mathrm{C}=\left({ }^{\circ} \mathrm{F}-32\right) / 1.8$

Vertical coordinate information is referenced to North American Vertical Datum of 1929 (NAVD 29).

Horizontal coordinate information is referenced to the World Geodetic System datum of 1984 (WGS84).

Altitude, as used in this report, refers to distance above the vertical datum. 



\title{
Debris Flow from 2012 Failure of Moraine-Dammed Lake, Three Fingered Jack Volcano, Mount Jefferson Wilderness, Oregon
}

\author{
By David R. Sherrod ${ }^{1}$ and Barton B. Wills ${ }^{2}$
}

\section{Introduction}

In the late spring or early summer of 2012, a flood emanated from a small moraine-dammed lake on the northeast flank of Three Fingered Jack in the Mount Jefferson Wilderness. Channel erosion or slope collapse breached the natural dam of the lake, leading to a sudden lowering of lake level by $2.8 \mathrm{~m}$ and discharge of 12,700 cubic meters $\left(\mathrm{m}^{3}\right)$ of water. The resulting debris flow formed a bouldery deposit extending about $0.35 \mathrm{~km}$ downslope (fig. 1).

The Three Fingered Jack debris flow is one of several that have issued from moraine-dammed lakes in the Oregon Cascade Range. A thorough summary of those lakes and the hazards associated with them was published in 2001, based largely on fieldwork by Jim O'Connor and Jasper Hardison in the early 1990s (O'Connor and others, 2001). Described here are details of the 2012 event, an update to the O'Connor story begun earlier.

\section{Setting and Previous History}

The 2012 debris flow originated at the head of Canyon Creek, which drains the northeast flank of Three Fingered Jack (fig. 2). Headwaters include a small moraine-dammed lake at about $1,840 \mathrm{~m}$ above sea level $(6,040 \mathrm{ft})$. The moraine is probably a composite of several neoglacial ice advances, as judged by its sharp-crested form, steep unstable slopes, and proximity to the perennial snowfield in the northeast cirque of Three Fingered Jack (Scott, 1977). The cirque was reoccupied by glaciers in late neoglacial time, or "Little Ice Age," which corresponds to the past several centuries, with glacial maxima occurring in the late 1800s (Porter and Denton, 1967; O'Connor and others, 2001). The moraine may have ice at its core because small landslip scars that appear sporadically on the moraine face usually remain wet through the summer and early autumn (Scott, 1977).

The moraine-dammed lake formed when ice retreated from its end-moraine position in the early 20th century. Timing of lake formation is inferential, as the lake was described in 1937 but goes unmentioned or depicted in earlier publications

${ }^{1}$ U.S. Geological Survey, Vancouver, WA 98683.

${ }^{2}$ U.S. Forest Service, Bend, OR 97701. and maps (O'Connor and others, 2001). Today the lake is fed by melt from the much-diminished glacier, now merely a permanent snowfield on the deeply shaded northeast flank of Three Fingered Jack. Lake water makes its surface discharge through a notch in the moraine (fig. 3) and, from there, cascades down a shallow canyon about $120 \mathrm{~m}$ long with a thalweg slope of $25^{\circ}-35^{\circ}$. The canyon opens downslope onto an alluvial fan coated by previous lake-breach debris flows of the 20th century. This alluvial fan flattens and terminates northward and westward against montane slopes. Canyon Creek drains the fan northeastward.

\section{Debris Flow}

\section{Extent and Volume}

The 2012 debris flow swept northward about $350 \mathrm{~m}$ from the lake to its distal margin (fig. 2); related silty mud extends another $80 \mathrm{~m}$. The area affected, about 2.63 ha (6.50 acre), is divided into three zones on the basis of deposit characteristics. Zone 1 is an upper erosional zone inset into the narrow lakeoutlet canyon. No deposition occurred in zone 1 during the 2012 event; instead, near-vertical and freshly eroded canyon walls, which are formed of nonindurated till, suggest the debris flow entrained most of its sediment here as the canyon walls collapsed (fig. 4).

Zone 2, midslope, is where the flow deposited the bulk of its debris. Slope diminishes from $15^{\circ}$ to $5^{\circ}$ across zone 2 . Debris thickness is generally less than $1 \mathrm{~m}$ in zone 2 , which has an area of about 1 ha ( 2.5 acre). Thickness was determined at several sites where the base of the deposit could be seen overlying 2011-12 winter snowpack (fig. 5).

Zone 3, farthest downslope, is a flat to gently sloping area that was blanketed by a few centimeters of silty mud during the 2012 event. Like the debris-flow deposit, the mud was emplaced on existing snowpack. It coated any trees and shrubs that poked through the snow on adjacent slopes; height seen after complete snowmelt was a few centimeters to tens of centimeters above the deposit. This mud trimline also rings a few large boulders that were emplaced by rockfall decades before the debris-flow event. The trimline height, measured by total-station survey, indicates a nearly planar surface that sloped gently ( 0.5 percent $)$ 
downdrainage, with no evidence of anomalous run-up. This shallow gradient suggests that the muddy slurry ponded only briefly, if at all, in zone 3; otherwise a horizontal trimline would have been created. During a September 2012 survey, two or more months after deposition, the mud was still boggy, despite being a relatively thin deposit.

The mud in zone 3 most likely resulted from dewatering after the zone-2 debris deposit came to rest. Contiguity of the silty mud along the downslope limit of the zone-2 deposit is similar to that seen in deposits of controlled flume experiments (R.M. Iverson, oral commun., 2014) or other reported moraine-impounded lake breakouts (for example, Breien and others, 2008). In contrast, any mud flushed by lake-sourced streams in the days after the debris flow, although indistinguishable in character, would present a more restricted depositional pattern adjacent to the zone-2 deposits.

The volume estimate for the 2012 Three Fingered Jack debris-flow deposit, $<10,000 \mathrm{~m}^{3}$, is derived from areathickness relations in zones 2 and 3 and reported to one significant figure. The debris-flow volume is only a tenth to a twentieth of that from other central Oregon moraine-dammed lake breaches. Volume estimates for three of those, gauged by the amount of material carved from the moraines, are $120,000 \mathrm{~m}^{3}$ for 1942 Collier Glacier debris flow down White Branch; 130,000 $\mathrm{m}^{3}$ for 1970 Diller Glacier (Whychus Creek $^{1}$ ); and 200,000 $\mathrm{m}^{3}$ for 1966 East Bend Glacier (Soda Creek) (O'Connor and others, 2001).

\section{Lake Change}

The moraine-dammed lake in the northeast cirque of Three Fingered Jack was never large. Lake volume soon after ice retreat was an estimated $43,000 \mathrm{~m}^{3}$. The volume then decreased stepwise following dam failures, the first before 1960 (to 37,000 $\mathrm{m}^{3}$ ) and another between 1977 and 1983 (to 26,500 m³ ; fig. 6; O'Connor and others, 2001). The 2012 breach cut the lake volume to $13,800 \mathrm{~m}^{3}$, or about one-half the volume of the lake that had existed since the early 1990s (table 1). Today the lake holds only about one-third of its historically largest volume.

${ }^{1}$ Named approved 2005, U.S. Board on Geographic Names; listed in O'Connor and others (2001) as Squaw Creek.



Figure 1. View south-southeast across debris-flow deposits to neoglacial moraine, $500 \mathrm{~m}$ distant. Prominent bedded vent deposits on central skyline form the east flank of Three Fingered Jack volcano, summit of which is out of view to right (west). Yellow boxes outline areas of figures 4 and 5. Author photo DSCN0097, Aug. 6, 2012. 




WGS84 datum

\section{EXPLANATION}

2012 Debris-flow zones

\begin{tabular}{|c|c|}
\hline 1 & Erosional zone \\
\hline 2 & Bouldery debris-flow \\
\hline 3 & Silty mud \\
\hline & Permanent snow and ice \\
\hline 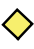 & 2014 snow survey \\
\hline
\end{tabular}

Figure 2. Map showing distribution of 2012 debris-flow deposit from moraine-dammed lake failure on northeast flank of Three Fingered Jack, Cascade Range, central Oregon. Lake extent is that of 2012 (shoreline c); shoreline ' $b$ ' is traced from lidar (2010); and shoreline of 1993 (labeled ' $a$ ') (O'Connor and others, 2001) coincides with 2010 shoreline except in southern part. Shift from shoreline 'a' to shoreline ' $b$ ' is driven mainly by prograding alluvial fan. Hillshade map provided courtesy of lan Madin, Oregon Department of Geology and Mineral Industries; lidar acquisition date 0ctober 9, 2010. Topographic contours shown for altitudes from 5,800 to 6,400 ft, at 200-ft interval, from Three Fingered Jack quadrangle (U.S. Geological Survey, 1988). 


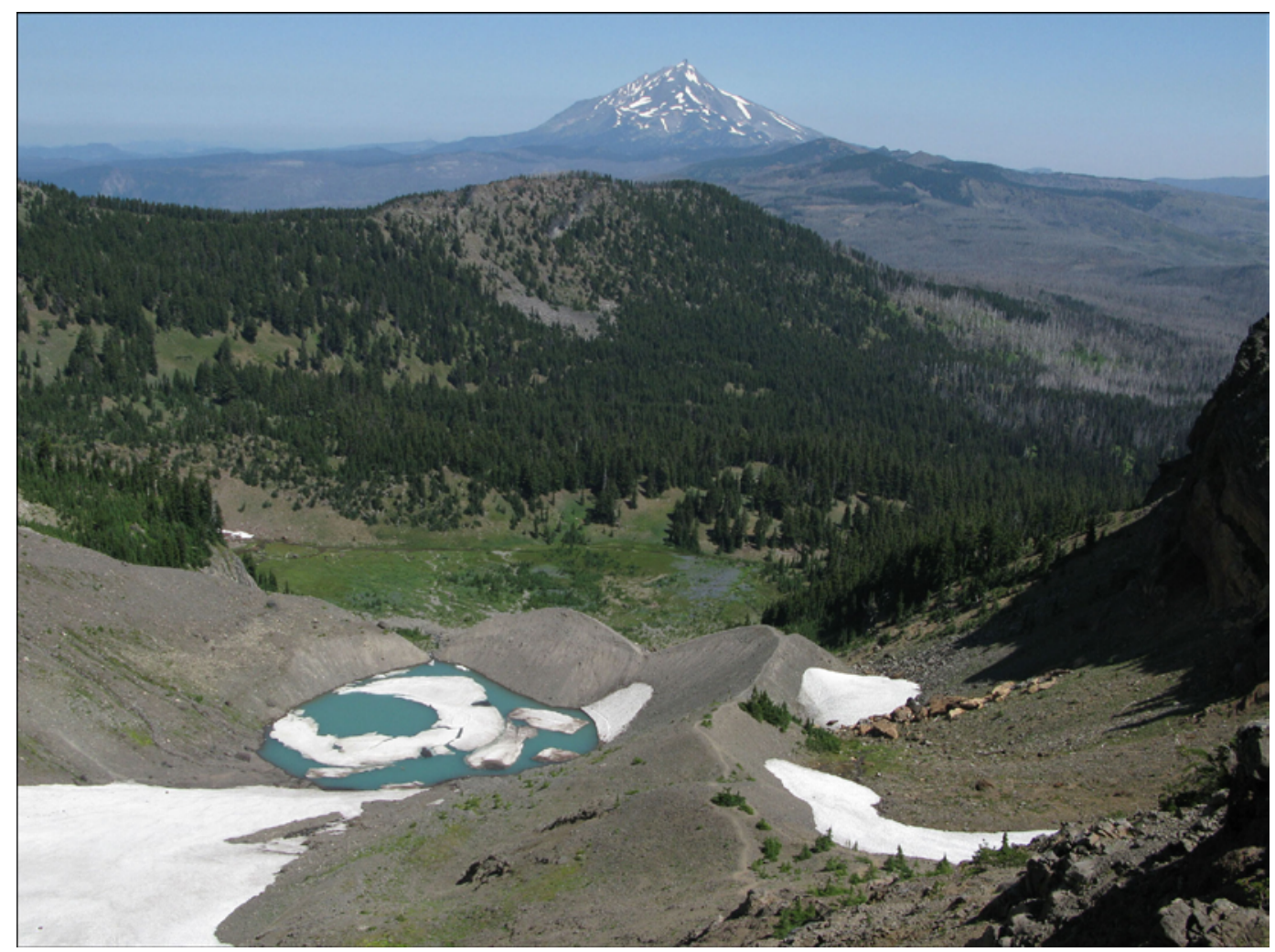

Figure 3. Cirque lake and lateral and terminal moraines on northeast flank of Three Fingered Jack. In distance $22 \mathrm{~km}$ north-northeast is Mount Jefferson (3,200 m; $10,497 \mathrm{ft})$. Altitude difference between lake and meadow is $85 \mathrm{~m}$ ( $280 \mathrm{ft})$. Stream from lake flows along left edge of meadow (track of 2012 debris flow), then right along north edge of meadow, to where it enters the canyon of Canyon Creek. Photo IMG_0847 taken Aug. 3, 2009, by Ken Bevis, used with permission.

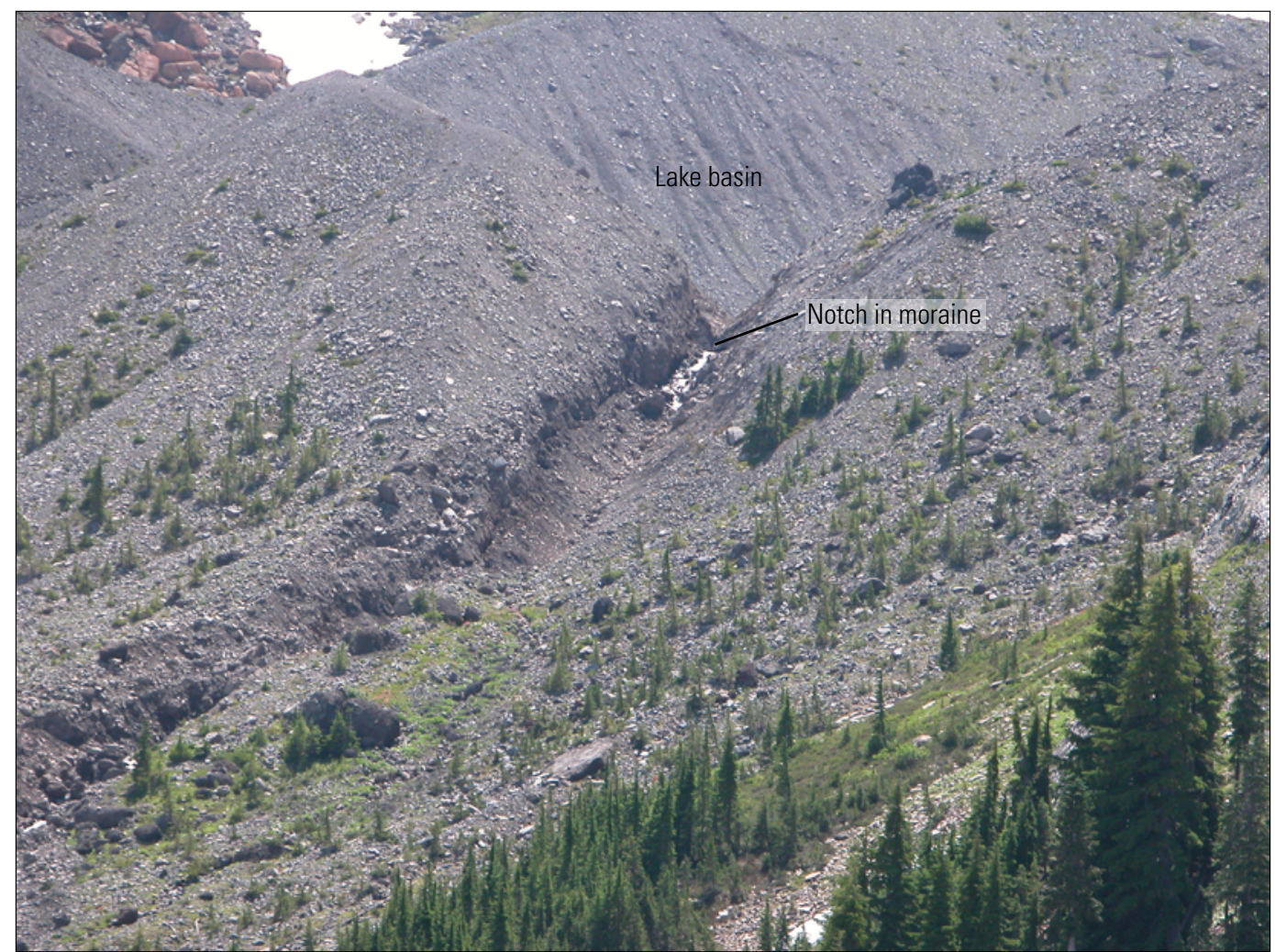

Figure 4. View southsoutheast into canyon that heads at moraine-dammed lake. Oversteepened canyon walls are consequence of 2012 lake breakout. Author photo DSCN0098, Aug. 6, 2012. 
Figure 5. Bouldery debris-flow deposit atop $1.5 \mathrm{~m}$ of snow, winter 2011-12 snowpack. Author photo DSCN0091, Aug. 6, 2012.
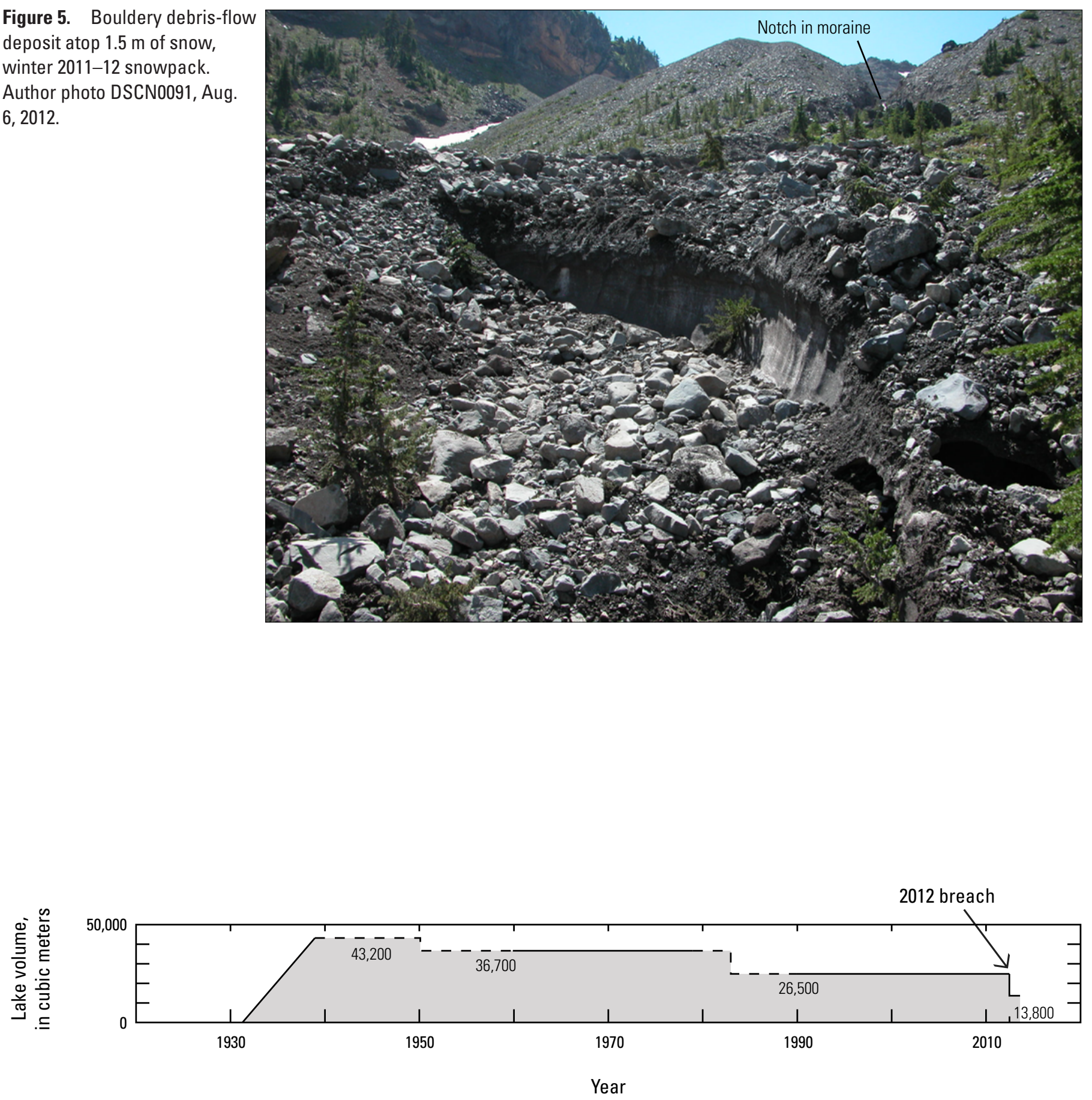

Figure 6. Time-volume graph for moraine-dammed lake on northeast flank of Three Fingered Jack. From 0'Connor and others (2001), modified to show loss from 2012 breach. 
Table 1. Geometric parameters for lake in northeast cirque of Three Fingered Jack.

[September 2012 data from new survey; 1993 data reported by O'Connor and others (2001). Survey of 2012 was limited by extensive ice floe. Divergence between 2012 lake lowering $(2.8 \mathrm{~m})$ and difference of surveys $(2.0 \mathrm{~m})$ is consequence of not finding deepest part of lake by leadline method]

\begin{tabular}{lcc}
\hline \multicolumn{1}{c}{ Lake geometry } & $\mathbf{1 9 9 3}$ & $\mathbf{2 0 1 2}$ \\
\hline Perimeter, $\mathrm{m}$ & 307 & 238 \\
Area, $\mathrm{m}^{2}$ & 6,120 & 3,946 \\
Maximum depth measured, $\mathrm{m}$ & 8.0 & 6.0 \\
Volume, $\mathrm{m}^{3}$ & 26,500 & 13,780 \\
\hline
\end{tabular}

When seen in August 2012, the lake's water level stood $2.8 \mathrm{~m}$ lower than an older prominent shoreline, and the slope between the shorelines was barren of vegetation and coated by mud (fig. 7). Higher up, the slopes host scattered alpine herbs and sparse prostrate shrubs. This older shoreline corresponds to the lake level that existed in the years following the 1993 O'Connor-Hardison survey (O'Connor and others, 2001). Its persistence through nearly two decades is shown by the near coincidence of the 1993 surveyed shoreline and a shoreline mapped from 2010 lidar data (shorelines a and b, respectively, on fig. 2). The 1993 shoreline is well developed on the western and eastern sides of the basin. It is poorly preserved along the south side where an alluvial fan extends into the lake, fed by sediment deposited from seasonal melting of the perennial snowfield. Shoreline preservation is nil on the north or northeastern side where the terminal moraine slopes steeply into the lake. For reference purposes, this older shoreline is taken as a datum ("0-m shoreline"), since it was the lake level of the only previous survey. The August 2012 lake surface becomes the -2.8-m shoreline.

Pre-1993 lake shorelines are also evident on the west side of the lake. They are characterized by exceedingly narrow benches (beach-backslope morphology). Two of these shorelines were mentioned by O'Connor and others (2001): $1.8 \mathrm{~m}$ and $2.6 \mathrm{~m}$ above the early $1990 \mathrm{~s}$ shoreline; positional error reported as $\pm 0.1 \mathrm{~m}$. The most prominent paleoshoreline stands $6 \mathrm{~m}$ above the early 1990s shoreline (fig. 8).

A lake-depth survey in September 2012 was limited by thick ice pack that remained on the lake throughout the summer (fig. 9A). The resulting bathymetric map (fig. 9B) relies in part on measurements from the 1993 survey (O'Connor and others, 2001) adjusted by subtracting the $2.8 \mathrm{~m}$ of depth drained by the 2012 moraine failure. This method does not account for 1993-2012 sedimentation. Depths plumbed during the 2012 survey were as great as $6 \mathrm{~m}$.

\section{Cause and Timing of the Moraine-Dam Failure}

In the absence of visual or instrumental monitoring records, the events leading to the 2012 lake breach and debris flow are known only by interpretation of the canyon's precipitous walls and the debris-flow deposit downslope. The instability of this canyon was noted previously:

\begin{abstract}
"This lake has one of the steepest outlets of the remaining moraine-dammed lakes [in the Oregon Cascade Range] and its seemingly precarious stability is apparently due to a few boulders, less than 1 $\mathrm{m}$ in diameter, that pave the channel thalweg at the outlet." (O'Connor and others, 2001, p. 45)
\end{abstract}

A triggering event may have been as simple as the undermining and erosion of one or two large boulders that armored the stream channel; or perhaps a landslip from the moraine face at or just below the lake outlet. The channel walls of the canyon leading downslope from the lake are susceptible to rapid erosion, so even a shallow nick into the natural dam could quickly lead to deluge. The debris-flow deposit shows no evidence for lengthy interlude during its emplacement.

\section{No Useful Satellite Imagery}

High-resolution satellite imagery would be needed to recognize the narrow band of the debris-flow deposit. Quickbird imagery, of submeter resolution, is available for January 31 and April 8, 2012. Subsequent imagery was acquired after July 29, when the lake breach had already occurred. The January imagery shows a snow-laden basin; the April imagery is cloudy across the head of Canyon Creek.

\section{Deposit Information about Emplacement Date}

Snow and ice about $1.5 \mathrm{~m}$ thick underlay the debris-flow deposit on the alluvial fan of zone 2 in late July 2012. This relation, exposed by thaw and stream erosion, indicates the debris flow was a late spring or summer event, occurring after the winter snowpack was well developed and already wasting. Mud coatings, some of them delicate, are preserved on shrubs in zone 3 of the deposit, and the mud trimline that rings the hillslope adjacent to zone-3 deposits suggests no substantial new snowfall occurred subsequently, the melting of which would have rinsed away some of the mud. 
Figure 7. View north along west side of lake. August 2012 lake level fell $2.8 \mathrm{~m}$ from prominent 1993 shoreline, which persisted at least through 2010 lidar acquisition date. Alpine vegetation dots the slope above the 1993 shoreline, whereas slope is devoid of vegetation and coated by mud below. Author photo DSCN0028, Aug. 6, 2012.


Figure 8. Highest(?) shoreline on west side of lake, $6 \mathrm{~m}$ above 1993 shoreline and $8.8 \mathrm{~m}$ above August 2012 lake. Woman for scale is 1.8 $\mathrm{m}$ tall. Author photo DSCN0034, Aug. 6, 2012. 



\section{EXPLANATION}

Bathymetry-Showing depth. Contour interval $2 \mathrm{~m}$; dashed at 5-m depth

- Measurement site, September 2012

Measurement, 1993 (0'Connor and others, 2001)—Showing sites within area of 2012 lake

Figure 9. Lake depth survey of September 7, 2012. A, Data were gathered by floating with leadline (for depth) and reflector prism; positional control by total-station measurements to the prism. Survey was hindered by unusually persistent late-summer lake ice. Author photo is mosaic of two frames from different vantages. $B$, Bathymetric map, drawn by combining 1993 and 2012 measurements. Base from 2010 lidar survey; Universal Transverse Mercator projection, zone 10N, datum WGS 1984. 


\section{Inferred Snow Conditions}

High-altitude weather stations are lacking in the Mount Jefferson Wilderness and surrounding area. The best proxy for conditions at the head of Canyon Creek may be Snow Telemetry (SNOTEL) site 651, a station maintained by the Natural Resources Conservation Service at 1,640 m (5,370 ft) on Mount Hood, $93 \mathrm{~km}$ to the north. A time-series depiction of snow thickness at site 651 for late spring-early summer months of 2012-14 is shown, with June 2014 measurements from the Three Fingered Jack area for comparison (fig. 10). The 2014 measurements were obtained by augering at several spots across the alluvial fan near the lower reach of the 2012 debris flow (fig. 2).

A notable trend on the snow thickness plot shows nearly linear wasting of snowpack - thinning at rates of 6-9 cm per day, and pausing only during inclement weather. Limited data from the 2014 snow survey at the head of Canyon Creek (X symbols on fig. 10) suggest a similar thinning rate. Also, the Canyon Creek 2014 snowpack was as much as $0.5 \mathrm{~m}$ thicker than that at Mount Hood site 651. As a field observation, when the snow at Three Fingered Jack was $1 \mathrm{~m}$ thick during our 2014 survey (June 30), snowpack still fully blanketed the lake, the meadows downslope of the lake, and the narrow canyon of Canyon Creek, down to an altitude of 1,710 m (5,600 ft) (see 2014 snow survey point in far-right corner of fig. 2). We surmise a similar setting characterized the area at the time of the moraine dam failure in 2012.

This line of evidence suggests emplacement of the debris flow in June or early July 2012. At that time, the snowpack would have been at least $1.5 \mathrm{~m}$ thick; and the debris-flow deposit (zone 2) and muddy sediment (zone 3), fully on snow, would have lacked a surface-stream connection to Canyon Creek, which would have flowed with clear, nearly sedimentfree water at lower elevation.

\section{Anecdotal Information about Emplacement Date}

A compilation of northern-hemisphere moraine-dam failures shows that all 50 of those with known dates occurred during the July through October melt season ( $\mathrm{O}^{\prime}$ Connor and others, 2001). Roughly 80 percent of the well-dated failures occurred in July and August, regardless of whether the failure was assigned to anomalous temperature (melting), precipitation, ice fall into a lake, or piping of the moraine dam. Thus, late spring and summer months are, statistically, the most likely time for moraine-dam failure.

The debris flow occurred before July 29, 2012, when Chris Stamper (U.S. Forest Service) and James Quiring (Oregon Department of Forestry) independently reported on the debrisflow deposit. Indeed, it was Quiring's notification that led to our site visit on August 6, 2012.

Additional observations by Stamper have bearing on the time when Canyon Creek finally tapped the muddy sediment at the toe of the debris-flow deposit (rather than the timing of the debris-flow event). He was working downstream in Canyon Creek in mid-July, at which time the creek was flowing clear. Two weeks later on his July 29 visit, the creek was milky with silt, the source of which was almost certainly the muddy deposit in zone 3 , at the foot of the debris-flow sequence. The

Figure 10. Snow thickness plot. Mount Hood data are from SNOTEL Site 651 for May, June, and July of years 2012-14, courtesy of Natural Resources Conservation Service (www. wcc.nrcs.usda.gov/snotel/Oregon/oregon. html). Data for head of Canyon Creek show measurements augered by us on June 3,13 , and 29 of 2014. The June 3 measurement failed to penetrate snowpack entirely; line upward from its value emphasizes range of likely thickness. Lengthy spans with near-constant slope correspond to snowpack thinning at rates of $6-9 \mathrm{~cm}$ per day.

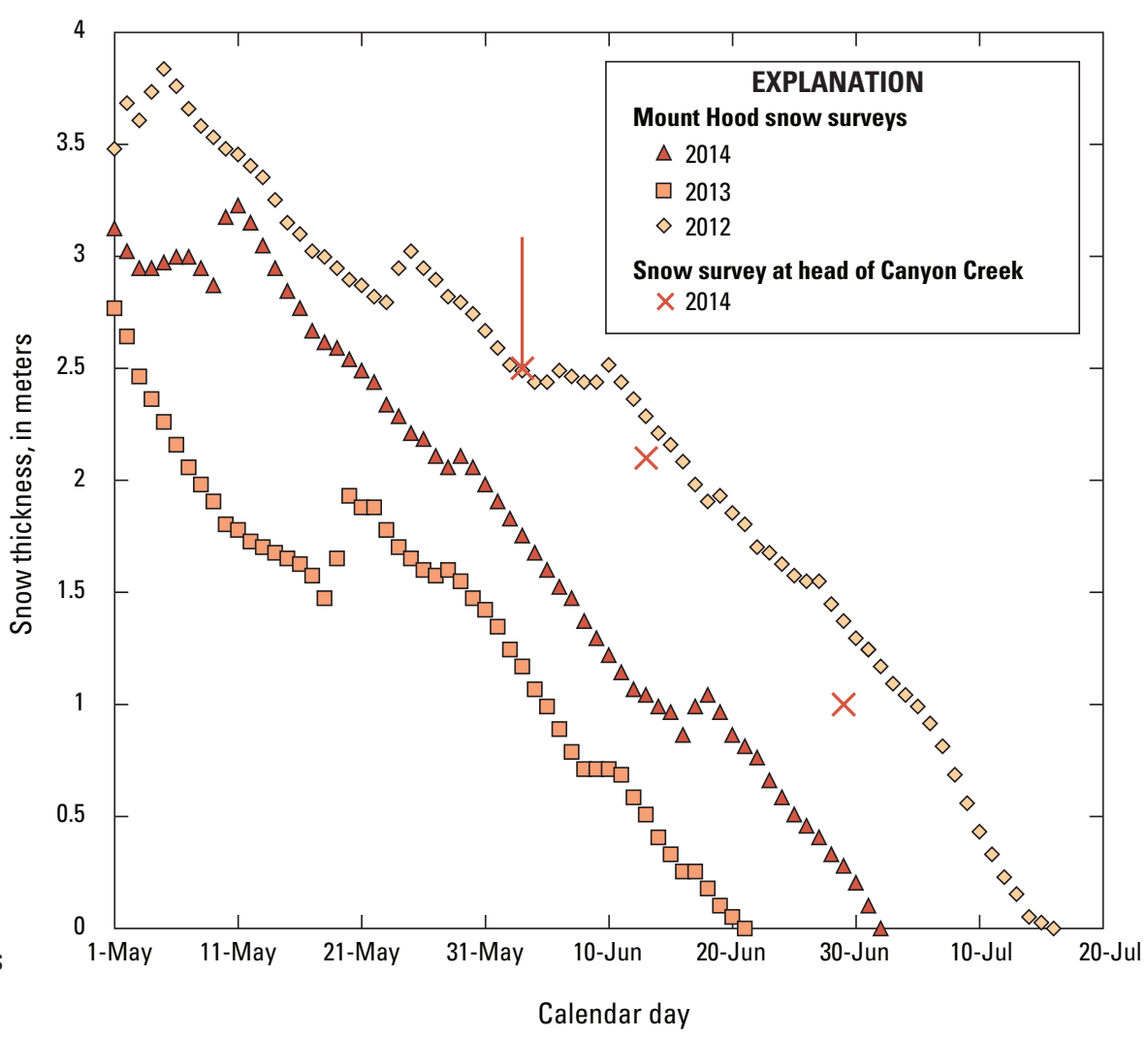


intervening two weeks mark the period in which snowpack disappeared entirely from the banks of Canyon Creek.

\section{Future Events}

Three Fingered Jack's northeast moraine-dammed cirque lake is poised for future dam failures that would produce debris flows on the alluvial fan downslope. However, a nearly complete breach would be necessary to create a flood equivalent in size to the 2012 or previous events. Smaller, incremental lake-lowering events are the likely scenario, resulting in less extensive debris flows. Regardless, the extent of the hazardous area remains unchanged for now and is defined as the path that may be swept by any debris flow emanating downslope from the moraine-dammed lake.

\section{Acknowledgments}

Julie Markus assisted in total-station surveys of lakeshore and downslope limit of debris flow. Turlough Scottel floated the lake for bathymetric survey and provided rodman service on total-station surveys. Aaron Rinehart assisted in the June 3, 2014, snow survey. Jenda Johnson served many roles on all those surveys, accompanying nearly every expedition into the Canyon Creek area. Roland Emetaz (ret.) and U.S. Forest Service Northwest Weather and Avalanche Center contributed the temperature-precipitation data from Timberline. Jim Quiring and Chris Stamper brought to our attention the debris-flow deposit and moraine-dam failure. Total-station data from the 1993 survey was provided by Jim O'Connor. Comments from reviewers Jim O'Connor, Jim Vallance, Willie Scott, and Sarah Nagorsen have enhanced the accuracy and readability of this report.

\section{References Cited}

Breien, H., De Blasio, F.V., Elverhøi, A., and Høeg, K., 2008, Erosion and morphology of a debris flow caused by a glacial lake outburst flood, western Norway: Landslides, v. 5, no. 3, p. 271-280, doi:10.1007/s10346-008-0118-3.

O'Connor, J.E., Hardison, J.H., III, and Costa, J.E., 2001, Debris flows from failures of Neoglacial-age moraine dams in the Three Sisters and Mount Jefferson Wilderness Areas, Oregon: USGS Professional Paper 1606, 93 p., http://pubs.usgs.gov/pp/1606/.

Porter, S.C., and Denton, G.H., 1967, Chronology of Neoglaciation in the North American Cordillera: American Journal of Science, v. 265, no. 3, p. 177-210, doi:10.2475/ajs.265.3.177.

Scott, W.E., 1977, Quaternary glaciation and volcanism, Metolius River area, Oregon: Geological Society of America Bulletin, v. 88, no. 1, p. 113-124, doi:10.1130/0016-7606(1977)88<113:QGAVMR>2.0.CO;2.

U.S. Geological Survey, 1988, Three Fingered Jack quadrangle: U.S. Geological Survey topographic map series, scale $1: 24,000$. 


\section{Appendixes A-B}




\section{Appendix A. Unrelated, Subsequent Snow Avalanche Dumped Trees onto the Snout of the Debris-Flow Deposit}

Contributing to the story of the debris flow is a snow avalanche that postdates the debris-flow deposit. The avalanche would be pertinent if its timing established a youngest possible age for the debris-flow deposit. Beginning at the steep slope of the Cascade Range crest, it traveled through mountain hemlock and white-bark pine, uprooting some and snapping many trees at $1.5 \mathrm{~m}$ height above ground, which likely corresponds to the thickness of the snowpack on that date. Most of the avalanche terminated on the irregular surface of a Pleistocene moraine north of the debris-flow deposit, but in August 2012 a trail of snags, limbs, and shredded needles extended downslope where they overlay the zone-3 deposits.

A temperature-precipitation record for the period of interest was sought in hopes that specific meteorological conditions might provide an emplacement date for the tree-laden snow avalanche. No convincing interpretation could be secured, but the weather record is included here, for completeness.

Since high-altitude weather stations are lacking in the Mount Jefferson Wilderness, the records shown here are for a station at 1,830 m (6,000 ft) on Mount Hood (Timberline), $95 \mathrm{~km}$ to the north, courtesy of the Northwest Weather and Avalanche Center. The Timberline data (fig. A1) show a spate of warm temperature readings (daytime highs of $75^{\circ}$ ) beginning on July 7. Previous temperature spikes lasting for a day or two occurred on May 14, May 7, and April 22. For precipitation, a notable storm hit the Mount Hood area on June 4-5, when 3.31 inches of rain fell in a 48-hour period.

\section{Appendix B. Index}

Tabulated here (table B1) are the locations for illustrations, tables, and text discussions of the moraine-dammed lake at Three Fingered Jack, as they appeared in O'Connor and others (2001).



Month in 2012

Figure A1. Graph showing Timberline (Mount Hood) precipitation and temperature data, courtesy of U.S. Forest Service Northwest Weather and Avalanche Center. 
Table B1. Index to key features of the lake and debris fan as discussed in 0'Connor and others (2001).

[Abbreviations: p., page; col., column; para., paragraph]





Menlo Park Publishing Service Center, California

Manuscript approved for publication October 24, 2014

Edited by Sarah Nagorsen

Design and layout by Cory Hurd 
